\title{
PARADIPLOMASI DALAM PERCEPATAN PEMBANGUNAN INFRASTRUKTUR FISIK DAN SOSIAL DI KABUPATEN BANTAENG
}

\author{
Ahmad Harakan \\ Program Studi Ilmu Pemerintahan, Fakultas Ilmu Sosial dan Ilmu Politik \\ Universitas Muhammadiyah Makassar \\ Email: ahmad.harakan@unismuh.ac.id
}

\begin{abstract}
This article illustrates and discusses the best practices of good governance and paradiplomacy activities in Bantaeng District. Especially after the era of reformation and globalization which is marked by the implementation of regional autonomy, decentralization and demands to realize good governance, where the provision of opportunities in the regions widely to maximize their potential, accelerated development and network development cooperation. By using descriptive qualitative research methods and data retrieval techniques, literature library and observation found interesting phenomena in the framework and the realization of government practice. Although Bantaeng regency statistically and physical appearance got negative opinion but with the existence of leadership integrity, relationships, cohesiveness and good coordination between the government and society, as well as efforts to realize good governance with the principles of learning and the development of wider relationships through international networks it can give an output on the acceleration of physical and social infrastructure development in Bantaeng Regency and even become best practice of good governance and paradiplomacy activity in Indonesia.
\end{abstract}

Keywords: Paradiplomacy, Development, Infrastructure, Good Governance.

\begin{abstract}
ABSTRAK
Artikel ini memberi gambaran dan mendiskusikan tentang praktik terbaik pelaksanaan tata kelola pemerintahan dan kegiatan paradiplomasi di Kabupaten Bantaeng. Utamanya setelah bergulirnya era reformasi dan globalisasi yang ditandai dengan pelaksanaan otonomi daerah, desentralisasi dan tuntutan mewujudkan tata kelola pemerintahan yang baik, dimana pemberian kesempatan pada daerah secara luas untuk memaksimalkan potensi yang dimiliki, akselerasi pembangunan dan pengembangan jejaring kerjasama. Dengan menggunakan metode penelitian kualitatif deskriptif dan teknik pengambilan data yaitu telaah pustaka dan observasi ditemukan fenomena menarik dalam kerangka dan perwujudan praktik pemerintahan. Meski Kabupaten Bantaeng secara statistik dan tampilan fisik sempat mendapatkan opini negatif namun dengan adanya intergritas kepemimpinan, relasi, kekompakan dan koordinasi yang baik antara pemerintah dan masyarakat, serta upaya mewujudkan tata kelola pemerintahan yang baik dengan prinsip pembelajaran dan pengembangan relasi yang lebih luas melalui jejaring internasional ternyata dapat memberi output pada akselerasi pembangunan infrastruktur fisik dan sosial di Kabupaten Bantaeng dan bahkan menjadi best practice good governance dan kegiatan paradiplomasi di Indonesia.
\end{abstract}

Kata Kunci: Paradiplomasi, Pembangunan, Infrastruktur, Tata Kelola Pemerintahan yang Baik. 


\section{PENDAHULUAN}

Di era reformasi di segala sektor, pemerintah dituntut untuk mewujudkan tata kelola pemerintahan yang baik (good governance). Terwujudnya good governance sebagai gambaran tata kelola pemerintahan yang terkini dianggap sebagai prestasi kekinian pemerintah yang diidamkan. Bahkan diskursus good governance telah menjajah wacana publik dalam reformasi dan demokratisasi di Indonesia (Prianto, 2011).

Era globalisasi yang menuntut terwujudnya inovasi dan pemerintahan yang unggul pada tingkatan apapun memandang perlunya menciptakan suasana dan kebijakan implementatif dan solutif dalam semangat good governance. Bahkan good governance merupakan simbol dari masuknya Indonesia dalam standar kehidupan global (Prianto, 2011).

Good governance menjadi simbol dari terlibatnya negara dalam standar global tidak sekedar difahami dengan pemaknaan sempit sebagai ruang kerja pemerintah pusat. Apalagi dalam diskusi tata kelola pemerintahan kontemporer dan isu desentralisasi, keberadaan pemerintah pusat tidak dapat dipisahkan dengan gerak langkah pemerintah daerah sebagai ujung tombak pelayanan dan pelaksanaan kebijakan.

Pemerintah daerah tidak dapat lagi diposisikan sekedar wakil pemerintah pusat yang memiliki wewenang di daerah. Dimana pemerintah daerah sekedar difahami sebagai aktor yang berkewajiban untuk mengambil intisari dari program pemerintah pusat lalu mengimplementasikannya dalam rencana pembangunan daerah. Karena wacana pemerintah daerah saat ini dalam usaha mewujudkan good governance adalah ikhtiar menghadirkan inovasi kreatif, pemberdayaan sumber daya manusia berdaya saing, dan membangun jejaring internasional dalam kerangka diplomasi dan kerja sama pada pemerintah maupun swasta yang memiliki best practice tata kelola pemerintahan yang unggul dan manajemen berdaya saing serta terbukti memberi perubahan pada kehidupan masyarakat.

Massifnya geliat partisipasi pemerintah daerah dalam kiprahnya secara internasional menandakan adanya momen perubahan fundamental yang sangat penting mengenai kedaulatan negara. Keberadaan Sistem Westhphalia yang memposisikan kedaulatan berada pada pemerintah pusat harus memahami dan berbagi peran dan kerja dengan pemerintah daerah dalam pelbagai kegiatan internasionalnya. Seberapa besar pembagian kedaulatan itu, tentu akan berbeda-beda tiap Negara (Wolff, 2007). Keadaan ini memudahkan pemerintah daerah untuk mengembangkan jejaring internasional melalui kegiatan paradiplomasi. 
Dalam praktik paradiplomasi maka aktor sub-state memiliki peran penting dalam melakukan hubungan luar negeri dengan tetap mengacu pada perilaku dan kapasitas dalam dalam rangka kepentingan mereka secara spesifik (Wollf, 2007). Bila mengacu pada Undang-Undang No. 24 Tahun 2000 mengenai Perjanjian Internasional dan UndangUndang No. 32 Tahun 2004 yang membahas tentang Pemerintahan Daerah yang kemudian direvisi sebanyak dua kali dengan terbitnya Undang-Undang No. 23 Tahun 2014 tentang Pemerintahan Daerah dan terakhir Undang-Undang Nomor 2 Tahun 2015 tentang Perubahan Kedua atas Undang-Undang No. 23 Tahun 2014 tentang Pemerintahan Daerah menandakan bahwa praktik paradiplomasi di Indonesia mempunyai ruang yuridis yang leluasa, sebab memberikan kewenangan kepada Pemerintah Daerah, baik provinsi maupun kabupaten/kota untuk melakukan hubungan dan kerja sama dengan pihak asing (Mukti, 2015).

Bahkan pada tahun 2010, Presiden Republik Indonesia saat itu yaitu Susilo Bambang Yudhoyono saat pertemuan bersama pengusaha yang berasal dari Australia mempersilahkan mereka untuk membangun jejaring dan menjalin komunikasi yang intens dengan pemerintah daerah (kabupaten/kota dan provinsi) di Indonesia, terutama para Gubernur untuk mengadakan investasi di Indonesia (Mukti, 2015). Adanya ruang yuridis dan kesempatan yang diberikan oleh pemerintah pusat kepada pemerintah daerah dalam menjalin komunikasi dengan jejaring internasional menandakan bahwa kesempatan mengembangkan dan mempercepat terwujudnya pembangunan di daerah perlu segera direspon dan patut dilaksanakan.

Dengan diberinya kesempatan dan restu pemerintah pusat serta dipacu dengan semangat dan keinginan mewujudkan good governance dalam pelaksanaan kebijakan dan pemberian pelayanan pada masyarakat, keadaan demikian memotivasi Pemerintah Kabupaten Bantaeng diawal kepemimpinan Nurdin Abdullah pada tahun 2008 lalu pada periode kedua pada tahun 2013 untuk membangun jejaring kerja sama dan hubungan luar negeri dalam praktik paradiplomasi. Selain itu kondisi realistis pembangunan di Kabupaten Bantaeng sebelum kepemimpinan Nurdin Abdullah yang memerlukan akselerasi perubahan dan pembangunan yang terukur sebagai mana yang terlihat dalam Sulawesi Selatan dalam angka 2007 yang diterbitkan oleh Badan Pusat Statistik Provinsi Sulawesi Selatan dan dengan tersuratnya semangat akselerasi dalam visi Pemerintah Kabupaten Bantaeng sebagai pusat pertumbuhan ekonomi dibagian selatan Sulawesi Selatan tahun 2018 dan merupakan titik temu dari pentingnya membangun relasi dan jejaring yang lebih luas. 
Artikel yang mendiskusikan tentang paradiplomasi dibahas oleh Mukti (2013) dalam artikel yang berjudul Sistem Pasca Westphalia, Interaksi Transnasional dan Paradiplomacy. Artikel ini menitikberatkan pada perlunya membangun interaksi transnasional yang menghadirkan aktor-aktor sub-state saat membangun jejaring dan melaksanakan aktifitas paradiplomasi dan tidak serta merta menghilangkan sendi utama kedaulatan negara, melainkan mampu menghadirkan tuntutan fundamental yaitu pembuatan aturan yang lebih jelas dan fokus membahas komitmen negara untuk melakukan share kedaulatan dalam batas-batas konstitusinya. Artinya keberadaan Paradiplomasi ini tidak memangkas bahkan menghilangkan peran pemerintah pusat dan kedaulatan negara.

Artikel kedua yang membahas mengenai paradiplomasi dalam geliat keterlibatan pemerintah daerah utamanya mengenai akselerasi pembangunan antara dibahas oleh Fathun (2016) yang mendiskusikan tentang implementasi praktik paradiplomasi dalam melakukan kerja sama penanaman modal asing untuk program unggulan yaitu smart city dalam rangka mewujudkan tata kelola pemerintahan yang baik (good governance) yang digambarkan melalui semangat akuntabilitas, transparansi, dan integritas di kota Makassar. Dengan adanya relasi dengan investor asing maka akan lebih memudahkan dan mempercepat pelaksanaan program smart city yang tidak sekedar memerlukan modal yang banyak namun perlu juga pembelajaran dan alih pengetahuan dalam implementasi program tersebut.

Artikel berikutnya mengenai paradiplomasi yang spesifik menyentuh problematika pemerintah daerah dibahas oleh Adibowo \& Putri (2016) yang mengelaborasi tentang penerapan e-government dalam paradiplomasi Pemerintah Kota Bandung. Adibowo \& Putri (2016) menerangkan bahwa Pemerintah Kota Bandung perlu mensinergikan penerapan E-Government dalam praktik paradiplomasi. Dengan cara demikian maka Kota bandung memiliki bargaining power dalam penerapan kerja sama dan citra Kota Bandung di dunia Internasional dapat dikenal dan menarik minat masyarakat internasional.

Pada tema kajian yang sama seperti tiga artikel sebelumnya juga dibahas oleh Susiatiningsih, Farabi, Paramasatya, \& Puspapertiwi (2018) dalam artikel berjudul memperkuat lokalitas Kota Semarang di era globalisasi melalui diplomasi lokal. Artikel ini membahas tentang pentingnya mengidentifikasi praktik diplomasi yang sesuai dengan konsep lokalitas kota semarang di era globalisasi. Praktik diplomasi yang dilaksanakan memiliki target awal yaitu terwujudnya kepentingan ekonomi seperti meningkatnya 
penanaman modal dan memperluas pasar, tanpa meninggalkan sisi identitas dan modalitas lokal yang dimiliki Kota Semarang.

Terkait kajian paradiplomasi di tingkat daerah melalui festival kebudayaan dibahas oleh Pasan (2017) dalam artikel tentang memaknai posisi pemerintah daerah dalam studi hubungan internasional: paradiplomasi Kabupaten Kutai Kartanegara dalam penyelenggaraan Erau International Folk Art Festival (EIFAF). Diskusi dalam artikel ini terkait dengan kepentingan Pemerintah Kabupaten Kutai Kartanegara dalam penyelenggaraan EIFAF terbagi menjadi dua yakni kepentingan ekonomi dan kepentingan kultural. Dan Implementasi dari paradiplomasi Pemerintah Kabupaten Kutai Kartanegara dijalankan dalam tiga bentuk yakni sebagai sponsor, koordinator dan komunikator.

Dengan menggunakan metode penelitian kualitatif deskriptif dan teknik pengambilan data yaitu telaah pustaka (library research) dan observasi serta berdasarkan pada uraian masalah dan state of the art diskusi artikel yang telah dipaparkan sebelumnya maka artikel ini akan memberi gambaran dan mendiskusikan mengenai kegiatan paradiplomasi dalam percepatan pembangunan terkhusus pada infrastruktur fisik dan sosial di Kabupaten Bantaeng. Bahasan ini dianggap penting untuk menambah khazanah kajian, rekomendasi kebijakan dan best practice tata kelola pemerintahan yang baik dalam kerangka dan kegiatan paradiplomasi.

\section{PEMBAHASAN}

\section{Rasionalitas Pemerintah Daerah Dalam Praktik Paradiplomasi di Kabupaten Bantaeng}

Diskusi terkait dengan percepatan pembangunan infrastruktur baik dibidang fisik maupun bidang sosial seringkali dihubungkan dengan ketersediaan modal. Bahkan modal dianggap merupakan salah satu prasyarat pertumbuhan ekonomi, bercermin pada angka pertumbuhan perekonomian Asia yang menakjubkan sebetulnya didorong oleh masuknya modal asing. (Jatmika, 2001). Masuknya modal asing menjadi harapan baru dalam proses pembangunan sebuah daerah. Bagi daerah berkembang biasanya memiliki problem awal dalam pembangunan, yaitu terletak pada kelangkaan keberadaan modal untuk pembangunan itu sendiri, sehingga bila daerah tersebut memiliki keinginan untuk meraih pertumbuhan ekonomi dan akselerasi pembangunan yang signifikan maka perlu untuk meraih modal utamanya berasal dari pemodal asing. 
Kemampuan untuk menyiapkan lahan investasi dan mengelola bahkan sampai memberi jaminan keberlangsungan dan manfaat investasi pada setiap jenis investasi apapun di daerah tersebut sangat diperlukan, hal ini sehubungan dengan ketertarikan pihak lain utamanya investor dari luar negeri untuk menanamkan modal. kemampuan pemerintah daerah mengelola investasi asing tersebut berbanding lurus dengan besarnya keinginan sebagian orang akan keuntungan atau minimalisir kerugian terhadap investasi yang telah diberikannya di tempat tersebut. Kerja sama luar negeri yang dilakukan oleh pemerintah daerah atau yang disebut paradiplomasi merupakan kebutuhan bagi daerah sebagai komponen pendukung percepatan laju pembangunan daerah melalui investasi dan peningkatan perdagangan internasional (Dwiyanti, 2018).

Apalagi di era kekinian setelah bergulirnya otonomi daerah maka timbullah prospek yang menggairahkan bagi aktivitas perdagangan dan investasi di daerah, di mana keduanya memainkan peranan penting dalam mendorong pertumbuhan ekonomi daerah. Hal ini dapat dimaknai dalam dua poin yaitu pertam $a$, terbukanya lapangan pekerjaan bagi masyarakat daerah akan berkorelasi positif dengan peningkatan penduduk. Kedua, mendorong peningkatan pendapatan pada sisi penerimaan daerah dalam bentuk pajak dan retribusi. Ukuran pertumbuhan ekonomi daerah dapat dilihat dari output yang dihasilkan dan pemanfaatan sumberdaya di daerah yang dilakukan lebih optimal sehingga memotivasi proses pertukaran produksi lintas daerah maupun lintas sektor (Chalid, 2005).

Meskipun tantangan tren kerja sama dunia ke depan bagi pemerintah daerah baik di tingkat Provinsi ataupun Kabupaten/Kota dapat dikatakan sulit dikarenakan belum pernah ada gambaran mengenai tradisi birokrasi yang mengarah pada kegiatan tersebut di masa yang lampau. Fakta bahwa praktik paradiplomasi merupakan hal yang baru di Indonesia maka perlu adanya Master Plan yang akan menjadi petunjuk bagi pemerintah daerah untuk melaksanakan kerja sama dengan stakeholder di luar negeri. Bahkan lebih spesifik diharapkan pemerintah pusat dapat mengarahkan orientasi kerja sama dengan pihak di luar negeri yang dilakukan oleh pemerintah daerah secara mandiri.

Adanya fakta dalam literatur dan pengalaman pemerintahan yang ada saat ini dimana pemerintah daerah tidak terlalu leluasa menentukan partner kerja sama dengan stakeholder dari luar negeri sehingga kadangkala nilai dari kemanfaatannya kurang jelas serta jarang sekali mendukung kebijakan makro hubungan luar negeri secara nasional, misalnya tentang kebijakan pasar bebas. Meskipun begitu dalam konteks Indonesia, salah 
satu bagian dari unsur sub-negara yang kemudian mengalami transformasi masif dalam hal kapabilitasnya adalah Provinsi serta Kabupaten/Kota (Pasan, 2017).

Berawal dari Undang-Undang No. 22 Tahun 1999, faktanya memang memberikan keberpihakan kepada Pemerintah Daerah untuk melaksanakan kewenangan dalam membangun jejaring internasional dan menentukan hal-hal apa saja yang akan dilakukan melalui skema kerja sama namun selain yang dikecualikan dalam undang-undang tersebut tersebut terlihat bahwa diskursus mengenai teknis kerja sama luar negeri ini cukup dinamis. Pada era sebelumnya dalam pelaksanaan kerja sama luar negeri maka daerah otonom tetap berpedoman pada aturan yaitu Peraturan Menteri Dalam Negeri Nomor 1 Tahun 1992 mengenai penyelenggaraan dan hubungan kerja sama luar negeri di jajaran Departemen Dalam Negeri. Setelah lahir Undang Undang No. 22 Tahun 1999 maka terbitlah peraturan pemerintah dan kewenangan provinsi sebagai daerah otonom yang dengan tegas menyatakan bahwa Pemerintah Pusat berwenang menetapkan pedoman tata cara kerja sama dengan lembaga/badan di luar negeri (Mukti, 2013).

Dari Undang-undang dan peraturan-peraturan yang sudah ada maka terjadilah perkembangan-perkembangan yang positif hingga akhirnya muncul kembali UndangUndang Nomor 32 Tahun 2004 yang dengan tuntas dan jelas memberikan kesempatan secara luas terhadap daerah otonom untuk membangun jejaring internasional dan menentukan bidang-bidang apa saja yang akan dikerjasamakan, selain yang dikecualikan dalam Undang-Undang tersebut (Mukti, 2013). Undang-Undang No. 32 Tahun 2004 kemudian hari direvisi sebanyak dua kali dengan diterbitkannya Undang-Undang Nomor 23 Tahun 2014 tentang Pemerintahan Daerah dan terakhir Undang-Undang Nomor 2 Tahun 2015 tentang Perubahan Kedua atas Undang-Undang Nomor 23 Tahun 2014 tentang Pemerintahan Daerah.

Dalam Permendagri No. 3 Tahun 2008 pun diatur mengenai pelaksanaan kerja sama luar negeri oleh pemerintah daerah yang dimana kewenangan berada pada wilayah interseksi antara urusan luar negeri dan dalam negeri yang masing-masing ditangani oleh kementerian yang berbeda, maka wajar sekali jika kedua kementerian itu, yakni Kemenlu dan Kemendagri mengeluarkan produk hukum yang berbeda satu sama lainnya. Seperti yang tergambarkan dalam pasal 3 disebutkan bahwa kerja sama pemerintah daerah dengan pihak luar negeri berbentuk, kerja sama provinsi dan kabupaten kota/kota kembar, kerja sama teknik termasuk bantuan kemanusiaan, kerja sama pernyataan modal, dan kerja sama lainnya sesuai dengan peraturan perundangan. 
Kabupaten Bantaeng dibawah kepemimpinan Nurdin Abdullah dalam catatan statistik menandakan kabupaten tersebut menjadi daerah yang perkembangannya sangat menonjol bukan hanya di tingkat Provinsi Sulawesi Selatan, tetapi juga di tingkat Nasional. Perkembangan yang sangat pesat itu, tak lepas dari kerja keras Nurdin Abdullah selama menjabat sebagai orang nomor satu di Bantaeng (Syah, Cangara, \& Sultan, 2016). Menurut Data Badan Pusat Statistik Kabupaten Bantaeng Tahun 2014, pertumbuhan ekonomi Kabupaten Bantaeng sejak diawal kepemimpinannya pada tahun 2008 sebesar 6,73 persen dan mengalami peningkatan yang cukup signifikan pada awal periode kedua di Tahun 2013 yaitu sebesar 8,82 persen (Indonesia, 2014).

Semangat menggelorakan dan menyambut investasi di Kabupaten Bantaeng dalam percepatan pembangunan bahkan dimulai sejak awal kepemimpinan bupati Nurdin Abdullah. Untuk menyukseskan kegiatan tersebut, Pemerintah Kabupaten Bantaeng telah melibatkan beberapa pihak yang mendukung kegiatan investasi dan kerjasama ini. Pemkab Bantaeng sebagai pihak yang dalam kegiatan kerja sama bahkan memberikan fasilitas dan pelayanan prima yang dibutuhkan investor seperti akses data pembangunan, fasilitasi pembebasan lahan, dan pembebasan retribusi (Kadir, Majid, \& Nurlinah, 2014).

Tindakan Pemerintah Kabupaten Bantaeng dengan mempermudah akses investor menandakan bahwa adanya rasionalitas dalam praktik paradiplomasi dan keinginan untuk menciptakan trust dan investor kepada pemerintah dan jaminan pemerintah kepada investor. Untuk memudahkan kegiatan investasi di Kabupaten Bantaeng, pemerintah daerah juga maka Pemerintah Kabupaten Bantaeng membentuk Kawasan Industri Bantaeng (KIBA) sebagai pusat kegiatan industri pengolahan yang dilengkapi dengan sarana dan prasarana seperti lahan dan lokasi yang strategis, fasilitas penunjang lainnya, seperti listrik, air, telepon, jalan, tempat pembuangan limbah, dan lain-lain yang telah disediakan oleh perusahaan pengelola kawasan industri (Kadir, Majid, \& Nurlinah, 2014).

Massifnya gerakan Pemerintah Kabupaten Bantaeng dengan mempermudah akses investasi utamanya penanaman modal asing tentu tidak tepat bila difahami dalam pandangan negatif seperti mendapatkan kerugian, penjajahan daerah, apalagi bila beranggapan bahwa investasi asing merupakan bentuk kegagalan mempertahankan kedaulatan. Melainkan bahkan mendapatkan manfaat efisiensi ekonomi (Afin, Yulistiono, \& Oktarani, 2008). Selain itu dengan adanya kemampuan tata kelola pemerintahan yang selama ini berjalan baik di Kabupaten Bantaeng mengindikasikan anggapan itu tidak benar 
melainkan Kabupaten Bantaeng siap bertransformasi dan memantaskan posisinya dengan semangat geliat lokal dalam interaksi global.

\section{Geliat Pembangunan Infastruktur Fisik dan Sosial di Kabupaten Bantaeng}

Era desentralisasi di Indonesia pasca berakhirnya rezim pemerintahan Soeharto tahun 1998 pada dasarnya telah memberikan ruang yang lebih leluasa bagi Pemda untuk berperan lebih aktif untuk ikut memajukan pembangunan yang mensejahterakan (Isnaeni, 2013). Secara teoritis pemerintah daerah (local government) baik tingkat I maupun tingkat II, bisa dikatakan sebagai aktor baru dalam studi maupun pelaksanaan hubungan internasional, munculnya aktor baru yang bernama pemerintah daerah (local government) mempengaruhi pengembangan model hubungan yang bersifat transnasional (Jatmika, 2001). Sebagaimana dengan kehadiran Pemerintah Kabupaten Bantaeng dengan sigap merespon kesempatan dengan landasan teoritis yang jelas melalui pengembangan jejaring kerja sama internasional dalam praktik paradiplomasi. Apalagi Pelaksanaan desentralisasi dan otonomi daerah memiliki peluang, kesempatan dan tantangan memunculkan potensi daerah (Broto, 2015).

Dalam rangka percepatan pembangunan utamanya dalam pengembangan Kawasan Industri Bantaeng (KIBA), Pemerintah Daerah Kabupaten Bantaeng telah melakukan kerja sama dengan Perusahaan Listrik Negara (PLN) tentang pasokan listrik untuk Kabupaten Bantaeng. Keterkaitan antara investasi dan harapan mewujudkan Bantaeng Industrial Park bahkan mendorong pemerintah melakukan kerja sama dengan beberapa investor dari Malaysia, dan Tiongkok (Alfian, 2014). Melalui mekanisme kerja sama investasi joint enterprise dengan bentuk investasi power plant untuk ketersediaan listrik, investasi solar supplier, dan investasi port untuk pelabuhan sebagai sarana transportasi mendapatkan potensi keuntungan pasokan listrik yang terjamin, tumbuhnya sektor ekonomi baru di daerah selatan, dan bertambahnya kesempatan kerja bagi masyarakat Kabupaten Bantaeng. Permasalahan kesempatan kerja yang dimana seperti kita fahami bahwa penggangguran merupakan masalah terbesar bagi suatu negara, karena pengangguran menyebabkan pendapatan dan produktivitas masyarakat rendah yang pada akhirnya akan menimbulkan kemiskinan dan masalah sosial lain (Ningrum, 2008). Selain itu untuk meminimalisir pelanggaran dan kesalahan prosedur, relasi kerja sama ini diawasi dan dikontrol oleh Dewan KIBA yang dibentuk oleh Bupati Bantaeng, Nurdin Abdullah (Kadir, Majid, \& Nurlinah, 2014). 
Selain pengembangan Kawasan Industri Bantaeng (KIBA), Pemerintah Kabupaten Bantaeng berdasarkan Rencana Tata Ruang Wilayah (RTRW) Kabupaten Bantaeng Tahun 2012-2032 menggenjot terbentuknya kawasan yang mengedepankan konsep pengembangan di bidang agropolitan di Kecamatan Uluere dan Kecamatan Sinoa (Zulfahri, 2017). Untuk memudahkan akses kerja sama dan investasi maka poin penting dalam upaya pembangunan kawasan ini dengan memastikan ketersediaan infrastruktur pertanian yaitu prasarana jalan, prasarana irigasi, sarana produksi hasil pertanian, dan fasilitas umum dan sosial di dua kecamatan tersebut. Dari pembobotan berdasarkan standar pembobotan dinas pekerjaan Umum, ketersediaan infrastruktur di Kecamatan Sinoa dan Kecamatan Uluere secara eksisting sebagai bentuk dukungan terhadap kawasan agropolitan di Kabupaten Bantaeng berada pada kategori baik dengan nilai 90\% untuk Kecamatan Sinoa sedangkan 81,6 \% untuk Kecamatan Uluere (Zulfahri, 2017).

Pada bidang pemberdayaan masyarakat terkhusus pada pemberdayaan hutan desa, Pemerintah Daerah Sulawesi Selatan mendapatkan kepercayaan dan dmelalui program Sulawesi Agfor (Agroforestry \& Forestry) Project dari Pemerintah Kanada sejak tahun 2011. AgFor Sulawesi adalah sebuah proyek lima tahun yang bekerja sama dengan masyarakat lokal, kelompok masyarakat, organisasi pelestarian, universitas, dan pemerintah untuk meningkatkan pendapatan petani melalui sistem agroforestri dan sistem pengelolaan sumber daya alam. Proyek ini berusaha mengatasi tantangan pembangunan pedesaan di Sulawesi dengan meningkatkan mata pencaharian dan badan usaha (livelihood), mendukung tata kelola (governance), dan memperkuat pengelolaan lingkungan yang berkelanjutan (environment). Salah satu tempat pelakasanaan program bertempat di Hutan Desa Campaga di Kabupaten Bantaeng dan menunjuk organisasi masyarakat sipil Balang Institut sebagai mitra lokal yang kemudian bekerjasama bersama warga untuk menentukan strategi peningkatan tata kelola hutan desa dan dengan keikutsertaan Pemerintah Daerah Kabupaten Bantaeng sebagai pihak yang mendukung terlaksananya program Sulawesi Agfor di daerahnya. ( Burhan, 2016).

Kepercayaan yang diberikan oleh Pemerintah Kanada melalui skema bantuan pemberdayaan hutan desa memberi manfaat dalam peningkatan wawasan, pemberdayaan masyarakat, dan infrastruktur sosial di kawasan hutan desa. Peningkatan peran serta masyarakat sangat diperlukan dalam pembangunan termasuk dalam proses perencanaan dan pelaksanaan terutama yang menyangkut secara langsung kehidupan dan masa depan mereka (Razak, 2013). Selain itu keterlibatan masyarakat merupakan salah satu strategi 
membangun dan mewudjudkan tata pemeintahan yang baik (good governance) adalah melibatkan dan mendorong partisipasipasi masyarakat dalam setiap aktivitas penyelenggaraan pemerintahan (Muhammadiah, 2013).

Selain bidang pemberdayaan masyarakat hutan desa, Pemerintah Kabupaten Bantaeng juga konsen dalam memperhatikan dan membangun pusat-pusat pertumbuhan di wilayah pesisir. Dimana Kabupaten Bantaeng ditetapkan sebagai Kawasan Minapolitan sebagaimana diamanatkan di dalam Keputusan Menteri Kelautan dan Perikanan RI Nomor KEP.32/MEN/2010 tentang Penetapan Kawasan Minapolitan (Hasan, 2017).

Pemanfaatan wilayah pesisir terdiri dari pemanfaatan wilayah pesisir daratan dan pemanfaatan wilayah pesisir lautan, Kondisi infrastruktur wilayah pesisir Kabupaten Bantaeng sudah tersebar cukup merata, potensi sumberdaya pesisir dan kelautan, serta Arahan kebijakan penataan ruang dan pembangunan wilayah peisisir Kabupaten Bantaeng mengarah pada peningkatan dan pemanfaatan potensi sumberdaya pesisir. Sedangkan untuk penetapan pusat-pusat pertumbuhan wilayah pesisir terbagi atas 3 orde, yaitu orde I adalah Kecamatan Bantaeng dengan fungsi utama sebagai pusat transportasi, Orde II adalah Kecamatan Pa'jukukang dengan fungsi utama pusat pengelolaan hasil kelautan dan perikanan (KIT-KP) dan orde III dengan fungsi utama sebagai pusat kegiatan budidaya perikanan dan kelautan (Hasan, 2017).

Meskipun sampai saat ini pembangunan wilayah pesisir masih terkonsentrasi di Kecamatan Bantaeng dengan destinasi wilayah pesisir Pantai Marina dan Pantai Seruni yang menjadi wisata andalan Kabupaten Bantaeng dengan dilengkapi fasilitas ekowisata dan fasilitas infrastruktur fisik dan sosial yang lengkap. Kedepannya pemanfaatan lahan wilayah pesisir Kabupaten Bantaeng juga akan memperhatikan kondisi dan peluang pembangunan di Kecamatan Pajukukang dan Kecamatan Bisappu (Hasan, 2017).

Selain dibeberapa tempat yang telah dipaparkan sebelumnya, dengan memanfaatkan peluang dan landasan teoritis dan yuridis paradiplomasi, Pemerintah Daerah Kabupaten Bantaeng juga berinovasi dalam pelaksanaan pelayanan publik di bidang kesehatan. Inovasi manajemen pelayanan publik di bidang kesehatan ini diwujudkan melalui keberadaan Emergency Service Team. Selain karena Kabupaten Bantaeng pada masa sebelumnya merupakan salah satu daerah yang sering terpapar bencana alam dan kurang memadainya pelayanan publik utamanya pelayanan kesehatan dan masalah sosial lainnya, maka tim ini dibentuk untuk merespon permasalahan tersebut (Tamimi, 2015). 
Dengan keberadaan Emergency Service Team memberi dorongan dalam perbaikan kualitas pelayanan publik dan percepatan pembangunan infrastruktur sosial. Standar dan manajemen pelayanan yang didapatkan melalui pengembangan relasi internasional dengan pihak pemerintah dan swasta di Jepang memberi manfaat dalam mengeliminasi pemborosan operasional, adanya pembagian tugas yang jelas dan terstruktur, adanya standar kerja yang aman dan dinamis, kemudahan dan kejelasan informasi bagi masyarakat, adanya respond time pelayanan yang jelas dan pasti, alih teknologi dan infrastruktur berupa mobil pemadam kebakaran yang sesuai dengan medan dan kebutuhan, ambulans dengan fasilitas yang lengkap setara unit gawat darurat di rumah sakit, serta revolusi mental untuk mewujudkan sumber daya manusia di Kabupaten Bantaeng yang unggul dan berintegritas sebagaimana sesuai dengan dasar filosofi kaizen yang diambil dari Negara Jepang (Tamimi, 2015).

Best Practice Pemerintah Daerah Kabupaten Bantaeng yang telah dipaparkan sebelumnya bukan tanpa hambatan. Seluruh ikhtiar yang dilakukan untuk memperbaiki kondisi dan mengadakan infrastruktur fisik dan sosial seringkali mendapatkan hambatan utamanya ditengah opini yang berkembang tentang Kabupaten Bantaeng yang tergambarkan negatif saat itu. Namun berbekal integritas kepemimpinan, relasi yang baik antara pemerintah dan masyarakat, serta upaya mewujudkan tata kelola pemerintahan yang baik dengan prinsip pembelajaran dan pengembangan relasi yang lebih luas melalui praktik paradiplomasi memberi output terhadap percepatan pembangunan infrastruktur fisik dan sosial di Kabupaten Bantaeng.

\section{KESIMPULAN}

Era pemerintahan kontemporer ditandai dengan tuntutan terwujudnya good governance disegala aspek. Ditopang dengan bergulirnya reformasi yang menjadi titik balik dari otonomi daerah dan desentralisasi pembangunan. Fenomena ini menjadi kesempatan luas bagi pemerintah daerah di Indonesia untuk mengembangkan potensi unggulan serta akselerasi pembangunan infrastruktur fisik dan sosial.

Berdasarkan aspek teoritis dan yuridis maka Pemerintah Kabupaten Bantaeng memanfaatkan momen dan peluang pengembangan potensi dan akselerasi pembangunan dengan melakukan perluasan jejaring internasional melalui praktik paradiplomasi. Meski seringkali mendapatkan hambatan, utamanya diawal pemerintahan Nurdin Abdullah sebagai Bupati, dimana kondisi Kabupaten Bantaeng dalam perhitungan statistik dan tampilan fisik mendapatkan respon negatif dan dianggap sulit dipasarkan. Namun berbekal 
integritas kepemimpinan, relasi yang baik antara pemerintah dan masyarakat, serta upaya mewujudkan tata kelola pemerintahan yang baik dengan prinsip pembelajaran dan pengembangan relasi yang lebih luas melalui jejaring internasional ternyata dapat memberi output pada akselerasi pembangunan infrastruktur fisik dan sosial di Kabupaten Bantaeng dan bahkan menjadi best practice good governance dan kegiatan paradiplomasi di Indonesia.

\section{DAFTAR PUSTAKA}

Adibowo, R., \& Putri, S. O. (2016). Penerapan E-Government Dalam Paradiplomasi Pemerintah Kota Bandung. Jurnal Ilmu Politik dan Komunikasi, 6(2).

Afin, R., Yulistiono, H., \& Oktarani, N. A. (2008). Perdagangan internasional, investasi asing, dan efisiensi perekonomian negara-negara ASEAN. Buletin Ekonomi Moneter dan Perbankan, 10(3), 261-296.

Alfian, M. F. (2014). Kerjasama Pemerintah Kabupaten Bantaeng dengan China Machinery Engineering Corporation (CMEC) dalam pembangunan Bantaeng Industrial Park (BIP) Tahun 2014.

Broto, M. F. (2015). Kerja Sama Luar Negeri Oleh Pemerintahan Daerah Menghadapi MEA 2015 (Kajian Konsep Paradiplomasi Dalam Khasanah Ilmu Pemerintahan). In: Seminar Nasional FISIP-UT 2015 : Peluang dan Tantangan Indonesia Dalam Komunitas ASEAN 2015, 26 Agustus 2015, Balai Sidang Universitas Terbuka (UTCC).

Burhan, Z. (2016). Efektivitas Bantuan Pembangunan Internasional dalam Program Sulawesi Agfor (Agroforestry \& Forestry) Project terhadap Pemberdayaan Hutan Desa Campaga Kabupaten Bantaeng, Sulawesi Selatan. WANUA : Jurnal Hubungan Internasional, 1(3), 63-73.

Chalid, P. (2005). Keuangan daerah, investasi, dan desentralisasi: tantangan dan hambatan. Jakarta: Kemitraan.

Dwiyanti, A. A. R. (2018). Dinamika Diplomasi Bencana Melalui Pendekatan Paradiplomasi oleh Pemerintah Daerah Sulawesi Selatan. Dauliyah Journal of Islamic and International Affairs, 3(1), 1-26.

Fathun, L. M. (2016). Paradiplomasi Menuju Kota Dunia: Studi Kasus Pemerintah Kota Makassar. Indonesian Perspective, 1(1), 75-94. 
Hasan, M. (2017). Analisis Pusat-pusat Pertumbuhan Wilayah Pesisir di Kabupaten Bantaeng (Undergraduate Papers, Universitas Islam Negeri Alauddin Makassar).

Indonesia, B. P. S. (2014). Indonesia Dalam Angka 2014. Jakarta: Badan Pusat Statistik Republik Indonesia.

Isnaeni, N. (2013). Peran Strategis Pemerintah Daerah dalam Kerja Sama Internasional untuk Pembangunan Berkelanjutan. Jurnal Global \& Strategis, 7(1), 123-138.

Jatmika, S. (2001). Otonomi daerah: perspektif hubungan internasional. Yogyakarta; BIGRAF Pub.

Kadir, H., Majid, M., \& Nurlinah, N. (2014). Analisis Kebijakan Penanaman Modal Asing di Kabupaten Bantaeng. Government: Jurnal Ilmu Pemerintahan, 7(1), 17-26.

Muhammadiah, M. (2011). Reformasi Pelayanan Publik Sebagai Strategi Mewujudkan Good Governance. Otoritas: Jurnal Ilmu Pemerintahan, 1(2).

Mukti, T. A. (2013). Paradiplomacy: Kerjasama Luar Negeri Oleh Pemda Di Indonesia, Yogyakarta: The Phinisi Press.

Mukti, T. A. (2013). Sistem Pasca Westphalia, Interaksi Transnasional dan Paradiplomacy. Jurnal Hubungan Internasional, 2(2), 175-183.

Mukti, T. A. (2015). Paradiplomacy: Bangkitnya Aktor Lokal di Fora Internasional. The POLITICS: Jurnal Magister Ilmu Politik Universitas Hasanuddin, 1(1), 85-94.

Ningrum, V. (2008). Penanaman Modal Asing dan Penyerapan Tenaga Kerja di Sektor Industri. Jurnal Kependudukan Indonesia, 3(2), 29-43.

Pasan, E. (2017). Memaknai Posisi Pemerintah Daerah Dalam Studi Hubungan Internasional: Paradiplomasi Kabupaten Kutai Kartanegara Dalam Penyelenggaraan Erau International Folk Art Festival (EIFAF). Jurnal Dinamika Global, 2(02), 18-41.

Prianto, A. L. (2011). Good Governance dan Formasi Kebijakan Publik Neo-Liberal. Otoritas: Jurnal Ilmu Pemerintahan, 1(1).

Puspapertiwi, S., Susiatiningsih, H., Farabi, N., \& Paramasatya, S. (2018). Memperkuat Lokalitas Kota Semarang di Era Globalisasi melalui Diplomasi Lokal. Jurnal Global \& Strategis, 12(1), 1-15. 
Razak, A. R. (2013). Peran Serta Masyarakat Dalam Pembangunan. Otoritas: Jurnal Ilmu Pemerintahan, 3(1).

Syah, D., Cangara, H., \& Sultan, M. I. (2016). Opini dan Sikap Masyarakat terhadap Pembaharuan dan Kepemimpinan Bupati Nurdin Abdullah dalam Memajukan Bantaeng sebagai Kota Industri dan Wisata. KAREBA: Jurnal Ilmu Komunikasi, 4(3), 300-314.

Tamimi, Z. (2015). Inovasi Manajemen Pelayanan Publik Tim Emergency Service Kabupaten Bantaeng. Politika: Jurnal Ilmu Politik, 6(1), 141-158.

Wolff, S. (2007). Paradiplomacy: scope, opportunities and challenges. The Bologna Center Journal of International Affairs, 10(1), 141-150.

Zulfahri, Z. (2017). Evaluasi Dukungan Infrastruktur Kawasan Agropolitan di Kabupaten Bantaeng (Studi Kasus: Kecamatan Uluere dan Kecamatan Sinoa) (Undergraduate Papers, Universitas Islam Negeri Alauddin Makassar). 